\title{
Tools, Techniques, and Methods of Finance and their Applications in Business
}

\author{
Sadaf Mustafa \\ Research Scholar, \\ Department of Commerce, University of Karachi
}

\begin{abstract}
Effective financial management involves intelligent use of financial tools, techniques and methods to determine and increase market value of firms. Its scope extends beyond accounting, budgeting, financial reporting and analysis. Its scope also goes beyond use of regular accounting tools like time value of money, working capital management, NPV analysis, make versus buy decisions, and investment analysis. In the broader domains of business, therefore, finance managers are expected to provide foresight for business strategy, helping the firms gain sustainable growth and expansion. The main purpose of this paper is to present and analyze the efficacy and relevance of the most pertinent tools used in the financial analysis. In order to achieve the purpose, secondary research is used to provide supporting evidence to determine the efficacy of each of the classical and contemporary financial tools. Extensive literature from research journals has been sought to present discussion on the relevance of these tools in light of growing changes in the world of finances, varying financial structures across the globe and rising need for ethical considerations in measurement and presentation of financial analysis and financial reports. This paper begins with a look at the basic valuation tools used by finance managers to assess a firm's value. It then moves to analyze advanced financial tools need to create and sustain firm value. Finally, the paper presents an examination of the legal and ethical insights into the use of these tools and techniques and advocates measures that should be adopted by decision makers in finance.
\end{abstract}

Keywords: Methods of Finance, Financial Tools, Finance Techniques

\section{INTRODUCTION}

Investors, creditors and financial managers use different techniques to determine a firm's value. Though most of such techniques are industry or company-specific, some stand generally acceptable and are extensively used for varied situations and business conditions (Ross et al. 2009). Four most commonly used techniques for determining a firm value are described below:

1. Discounted Cash Flow Analysis (DCF): This method involves determining a firm's value based on cash flow projections for the future. Once future cash flows are estimated, they are discounted using the net present value (NPV) techniques using a given rate of discount.

2. Comparable Company Analysis: This method is most frequently used to gauge values for public companies (Farooq \& Thyagarajan, 2014). Value is determined by comparing the company's financial standing and metrics with similar companies using the market prices.

3. Leverage Buyout (LBO): This method involves analysis whereby a firm's ability to pay is arrived at. The method involves arriving at the value on the basis of how well a company is able to acquire a significant amount of borrowed funds when a certain required rate of return is affixed to the borrowed capacity (Waddock \& Graves, 1997). 
In other words, LBO assesses a firm value based on its ability to pay given a certain RoR and debt/equity ratio.

4. Precedent Transaction Analysis: This method is particularly useful in situations where mergers and acquisitions have taken place. By analyzing the historical prices for any mergers/acquisitions that similar companies have had, valuation accounts for any 'control premium' and its rate over equity/revenue which the acquirer paid to have the business.

It is imperative to note that no single method can be applied across all situations.

Financial managers must look into the varying characteristics of the businesses they are valuing (Farooq \& Thyagarajan, 2014). Furthermore, investors are not advised always to rely on the same method. They may arrive at a range of firm valuations before arriving at a decision and they may average out all such valuations to see if they bring more precision (Milkman, Chugh \& Bazerman, 2008).

Contemporary techniques of financial management might include activities like risk management, performance management, competitive intelligence and use of big data for forecasting. The real or economic value of a firm (as against its accounting or book value) comes from the use of these very tools. By adopting these tools, the financial function becomes a main driver of value. Some other activities that also encompass or supplement the finance function may include one or more of the following:

1. Reducing cycle times through meaningful processing and inference of accounting and financial data.

2. Quicker closing of general ledger through data organization.

3. Leveraging technology and human resources to reduce lags, such as through use of electronic data interchange; electronic payroll processing and purchase credit cards for payables etc.

\section{Advanced Value Creation Tools}

The traditional approach to value creation focuses on historical accounting information and hardly accounts for the current and future market value of the organization (Ross et al. 2009). This puts the sustainability of investments at risk. The market valuation approach takes into account, not just earnings but expected cash flows for the future. The emphasis is thus shifted to economic performance rather than accounting performance (Tidd, 2012). Decision makers in finance are also expected to think outside the financial statements, quantify and measure non-financial parts such as human resource capital, information technology, research and innovation and strategic business partnerships (Tidd, 2012). These all impact the quality of earnings which the financial statements fail to reflect.

In order to arrive at the true picture of financial health, finance managers can make use of some advanced valuation techniques enlisted below.

1. Financial Restructuring

2. Market Value Added (MVA)

3. Residual Cash Flow (RCF)

4. Economic Value Added or EVA

5. Cash Flow Return on Investment or CFROI Cash Flow Return on Investment (CFROI)

\section{Financial Restructuring}

Financial restructuring is the basic value maximization technique used by modern large-scale businesses (Ross et al. 2009). Through it, financial outlook of a company can be improved 
through reconfiguration of business operations or business units or through purchase and sale of some other businesses or business assets (Cerný, 2009). A business restructuring can be in different forms including vertical restructuring, horizontal restructuring, corporate restructuring, recapitalizations and spin-offs (Ross et al. 2009).

1. In vertical restructuring, the configuration of assets of a business unit is changed. For example, a sale/lease arrangement can utilized for reconfiguration of the assets between two business units. Other instances of such restructuring include subcontracting and franchising (Farooq \& Thyagarajan, 2014).

2. In horizontal restructuring, either a new business venture or acquisition takes place, or a leveraged recapitalization takes place to improve a business capital structure (Ross et al. 2009).

3. In corporate restructuring, financial outlook is improved via issues of stocks/debt, repo transactions, leveraged buy outs (LBOs), liquidation and change in the form of business ownership (Waddock \& Graves, 1997).

4. In recapitalizations, or recaps, debt is used as a shield for an improved financial outlook. The firm incurs large debt in order to attract investments in future and also to ensure that they use their funds to their maximum potential and efficiency. Recaps force a business management to ensure high levels of cash and avoid any misuse or overuse of funds. In this way, value creation is maximized.

5. In spin off, a whole new company is created from an existing one, allowing value creation for shareholders as their share values are split into two parts: one of the old company and one of the new company (Ross et al. 2009).. This way a large part of trapped value of shares is released.

\section{Market Value Added (MVA)}

Public limited companies determine their market value by multiplying the number of their outstanding shares by market stock price (Cerný, 2009). Extending this concept further, the Market Value Added (MVA) model reflects the difference between market and invested values of this capital. It compares the cost of capital with its rates of return (ROR) to assess how well a firm is doing. Thus, MVA of a firm is presented by following steps:

$$
\text { MVA = Market Value of Equity + Market Value of Debt - Total Adjusted Capital }
$$

If market value of debt is not readily available, firms may only rely on the equity portion (Waddock \& Graves, 1997). Imperative to note here is that the valuation for capital originally invested cannot always be precise as accounting entries may cause distortion over time. However, the MVA approach is best applicable when firms need to benchmark their performance against others.

\section{Residual Cash Flow (RCF)}

Determining the residual cash flow (RCF) is one of the most important techniques firms use for value creation. Also called as cash value added (CVA) approach, RCF obtains the residual cash generated by a certain investment (Cerný, 2009). It is computed by subtracting the cost of capital from net cash flows and can be presented with the given formula:

$$
\text { RCF = Adjusted Operating Cash Flows }- \text { I (Gross Investment) }
$$

Where

I= Cost of Capital

$\mathrm{RCF}=$ Residual cash flow 
As an example, a capital asset with a $\$ 100,000$ cost has expected annual cash flows of $\$ 35000$. Assuming that marginal tax for this asset is 35\%, and weighted average cost of capital as $8.5 \%$, we can arrive at RCF as:

Cash Flows (per year) $=\$ 35,000$

Minus Taxes at rate of $35 \%(12,250)$

Net Cash Flows 22,750

Adjustment to Cash Flow (1) 7,000

Adjusted Cash Flow 29,750

Less Cost of Capital (2) (8,500)

Therefore, Residual Cash Flow (RCF) per Year \$21,250

Note that adjustments to cash flows have been calculated using the following steps:

1. Depreciation of $\$ 20,000$ per year $(\$ 100,000$ / 5 years $) \times .35$ tax rate.

2. Gross investment of $\$ 100,000 \times 8.5 \%$.

RCF is considered as the easiest approach to arrive at an investment valuation (Cerný, 2009). However, in order for RCF to be much accurate, certain adjustments are needed in the Weighted Average Cost of Capital and Operating Cash Flows. Furthermore, RCF cannot be applied as a comparable measurement tool (Waddock \& Graves, 1997). That is, we cannot compare two companies using their residual cash flows. The technique is more suitable for valuation of projects than for valuation of companies.

\section{Economic Value Added or EVA}

This technique, like the RCF approach discussed above, is also based on the notion that economic income rather than accounting income should reflect the financial outlook of a business. EVA was popularized by a financial consulting firm called Stern Stewart which made sure that it was adopted as and effective financial tool for corporations like Whirlpool, CocaCola, Boise Cascade, Monsanto, and Eli Lilly.

The basic formula for measuring EVA of a firm is presented by:

$$
\text { EVA }=\text { NOPAT }- \text { Cost of Capital }
$$

In the equation above $=$ NOPAT represents the 'Net Operating Profits after Taxes' which is the sum of cash equivalent equity that has been invested in the business and the cash equivalent of income (Cerný, 2009). On the other side, cost of capital represents the charge for use of capital, including interest on the debt and a charge for the equity capital based on a cash equivalent equity $x$ cost of equity rate (Ross et al. 2009). The EVA model assumes that economic income can be arrived when accounting distortions affecting net operation profits and capital are removed. The table below presents the adjustments that are made in EVA.

Table:1

\begin{tabular}{|l|l|}
\hline \multicolumn{1}{|c|}{$\begin{array}{c}\text { Adjustments Required to Calculate } \\
\text { NOPAT: }\end{array}$} & \multicolumn{1}{c|}{$\begin{array}{c}\text { Adjustments Required to Calculate } \\
\text { Capital: }\end{array}$} \\
\hline + Increase to Deferred Taxes & + Deferred Taxes \\
\hline + Increase to LIFO Reserve & + LIFO Reserve \\
\hline + Goodwill Amortized in Current Year & + Total Goodwill Amortized to Date \\
\hline + Increase to Net Capitalized Intangibles & + Net Capitalized Intangibles \\
\hline +/- Unusual Loss or (Gains) net of tax & +/- Cumulative Loss or (Gain) net of tax \\
\hline $\begin{array}{l}\text { + Increase to Other Reserves \& } \\
\text { Allowances }\end{array}$ & + Other Reserves \& Allowances \\
\hline
\end{tabular}




\section{Cash Flow Return on Investment or CFROI}

This method involves value measurement through an emphasis on operating cash flows adjusted for economic uncertainties such as inflation (Cerný, 2009). When such cash flows are arrived at, they are compared against returns to investments, which are also adjusted for economic uncertainties (Ross et al. 2009). This is done because market response to accounting information is not reflective of economic behaviors (Farooq \& Thyagarajan, 2014). The basic equation for CFROI is presented with the formula given below:

\section{CFROI = Inflation Adjusted Cash Flows (Cash In) / Inflation Adjusted Investment (Cash Out)}

Seeing the equation above, it can be deduced that CFROI is the ratio of cash in to cash out given an expected rate of return (ROR). Like EVA, this method will also involve adjustments to accounting distortions. Some common adjustments made in order to determine value through EVA are presented in the table below:

Table:2

\begin{tabular}{|c|c|}
\hline Net Income & Book Value of Assets \\
\hline $\begin{array}{c}\text { + Rent Expense (Operating } \\
\text { Leases) }\end{array}$ & $\begin{array}{c}\text { Accumulated } \\
\text { Depreciation }\end{array}$ \\
\hline - FIFO Profits & $\begin{array}{c}\text { Operating Leased } \\
\text { Assets }\end{array}$ \\
\hline + Interest Expense & $\begin{array}{c}\text { Net Deferred Tax } \\
\text { Assets }\end{array}$ \\
\hline
\end{tabular}

\section{Financial Structures of Firms}

A firm's financial structure can mainly be divided into equity and debt. Each firm, depending on the size and market in which it operates, may have a different financial structure, with some firms having more funds from equity and others more from finance (Ross et al, 2009). The financial structure of a firm will also depend on the extent and ease of internal and external sources financing (Tidd, 2012; Farooq \& Thyagarajan, 2014). Moreover, the size and operations of national equity markets, as indicated in national stock exchanges, banking and insurance sectors, may also impact on a firm's financial structure (Deesomsak, Paudyal \& Pescetto 2004).

The financial structures of global firms are generally reflective of their global strategy (Deesomsak, Paudyal \& Pescetto 2004). Global firms like Toyota, HP, Caterpillar and Du Pont would have a varied set of capital structure for each of the markets they operate, and some of their projects may even be having a zero or negative ROI (Hout, Porter \& Rudden, 1982). The reason for variations in financial performance targets of global firms is simple: they work for ousting local and regional competition and emerge as massive global businesses rather than small financial winners.

According to Porta et al (1997), UK and the US have colossal equity markets in relation to equity markets of France and Germany. While hundreds of firms become public limited companies in the US, only a few will be able to do so in Italy. In the banking line, Japan and Germany surpass their market size greater than those of some wealthier countries, and in Russia, companies may not be having any external finance at all. These variations in size, depth and valuation of capital markets across the world are in large due to variations in legal atmosphere. Countries which follow common law protect creditors and shareholders the most; countries that follow German civil law and Scandinavian civil law moderately protect shareholders and creditors; while countries which follow French civil law have least regard for 
creditors and shareholders. In general, wealthier countries are better in law enforcement than poorer ones. Porta et al (1997) also argued that countries more open to external finance will generate better valuations of stocks. It is therefore suggested that countries with stronger law enforcement take on the path of external finance to broaden their capital markets.

\section{Global Financial Markets}

Financial markets are arrangements wherein buyers and sellers exchange financial instruments such as bonds, stocks, options, derivatives, swaps, futures, as well as currencies and commodities, are exchanged (Ross et al, 2009). Financial markets operate under certain rules and procedures mandated by national and international legislation. Some financial exchanges, however, are made in private i.e. through middlemen and dealers who operate in over-the-counter markets, or through insurers who secure debt for an individual or a firm (Deesomsak, Paudyal \& Pescetto 2004). The dynamic nature of financial products and services demand a high degree of compliance not only for laws, principles and policies, but also for ethics (Benjamin, 2009). Financial markets are considered ethically responsible when they pose minimum amount of unfairness with regards to trading practices (Waddock \& Graves, 1997). Such unfairness may be found through instances of fraud and manipulation or in unfair business conducts such as window dressing of financial statements for purposes of tax evasion, unhealthy business competition, inaccurate or misleading financial announcements and the like.

It may sometimes be difficult to measure the size of financial markets because they are mainly dominated by the biggest firms (Porta et al, 1997). Smaller firms, be they hundred in number, may never even access stock markets unless they go through a formal registration and a given a legal access to stock market through issuance of shares to the public in the form of Initial Public Offers, or IPOs (Deesomsak, Paudyal \& Pescetto 2004).

The global financial markets consists of all national and international players engaged in financial dealings of stocks, currencies, commodities, bullions, foreign exchange, loans, deposits, insurance, reinsurance, trading instruments and the like. According to Beck, Kunt and Levine (2009), the size of global financial markets can be gauged by liquid liabilities, currency outside the banking system, stock market and bond market capitalization and private credits (Benjamin, 2009). These indicators could be used to determine how financial sector varies from one country to another (Beck, Kunt and Levine, 2009).

\section{Ethical and Legal Implications of Finance}

According to Richardson (2009), regulations relating to the financial sector must stress on the environmental cost' of funds of a business. The need for an environmentally responsible behavior must be reflected as a part of business practice through strict adherence to the concept of Socially Responsible Investment, or SRI (Benjamin, 2009). In it, the financiers are advised to look at the environmental outcomes of their investments (Richardson, 2009). The fiduciary duties of financial regulators are also need to be expanded to account for environmental costs. Such duties may also be financially incentivized by the regulators in the form of strong performance standards (Porta et al, 1997). Laws may also be developed in which financial reporting includes aspects of environmental costs and returns of investments.

The global financial markets registered heavy shocks from the financial crises that erupted in the year 2007. The unabated collapse of a few banks fuelled a vicious circle of disinvestments across the globe, with major financial markets taking years to absorb and respond to those shocks. Policymakers and researchers soon focused on the irregularities of financial markets 
that caused the crises, with greater focus on the issue of legislation targeting governance and control of financial markets (Boatright, 2010).

The issue of ethics in finance has received little focus from the research community (Boatright, 2010). Scholars appear to lack the research paradigm needed for the issue because of the absence of precise analytical tools or methods to determine how ethics impact business investments and profits (Ross et al, 2009). Scholars who have researched on business ethics also exclude these financial aspects given their limited understanding of theories and practices of finance.

Contemporary researchers in finance, however, are of the view that ethics should govern all company policies and procedures (Boatright, 2010). Without ethical fairness, they argue, businesses may register several financial and non-financial losses and may find it difficult to operate in stable market conditions (Benjamin, 2009).

\section{References}

Boatright, R, J. (2010) Finance Ethics: Critical Issues in Theory and Practice, John Wiley \& Sons,

Cerný, A. (2009) Mathematical Techniques in Finance: Tools for Incomplete Markets, Second Edition, Princeton University Press, Pg 20-79

Deesomsak R., Paudyal K., Pescetto, G. (2004) The determinants of capital structure: evidence from the Asia Pacific region, Journal of of Multinational Financial Management, Vol 14, pp 387-405

Farooq, S. and Thyagarajan, V. (2014) Valuation of Firm: Methods \& Practices-An Evaluation Harvard Business Review

Hout, T., Porter, E, M. \& Rudden, E. (1982) How global companies win out Reprinted from

Milkman, K.L., Chugh, D. \& Bazerman, M.H. (2008) How can decision making be improved? http://www.hbs.edu/research/pdf/08-102.pdf

Porta, L., R., De-Silanes, L, F., Shleifer, A., \& Vishny, R. (1997). Legal Determinants of External Finance. The Journal of Finance, 52(3), 1131-1150. doi:10.2307/2329518

Richardson, J. Benjamin (2009) Keeping Ethical Investment Ethical: Regulatory Issues for Investing for Sustainability, Journal of Business Ethics (2009) 87:555-572

Ross, W. et al (2009) Corporate finance: core principles and applications. 2nd ed., New York: McGraw-Hill/Irwin.

Thorsten, B. and Kunt, D, and Ross, L. (2009) Financial Institutions and Markets Across Countries and Over Time Data and Analysis (May 1, 2009). World Bank Policy Research Working Paper Series, Vol. , pp. -, 2009. Available at SSRN: https://ssrn.com/abstract=1414705

Tidd, J. (2012) From Knowledge Management to Strategic Competence: Assessing Technological, Market and Organisational Innovation Third Edition World Scientific Publishing Company, pp. 88-97

Waddock, S., \& Graves, S. (1997). The Corporate Social Performance-Financial Performance Link. Strategic Management Journal, 18(4), 303-319. Retrieved from http://www.jstor.org/stable/3088143 